\title{
The contribution of the Netherdutch Reformed Church of Africa (NHKA) to theological training at the Transvaal University College
}

\author{
P J van der Merwe \\ Department of Science of Religion and Missiology \\ University of Pretoria
}

\begin{abstract}
The ideal of theological training of candidates for the ministry of the Dutch Reformed Church (NHK) found its first (formal) expression in 1884. Difficult ecclesiastical, social and economic circumstances (including the consequences of the First and Second Anglo-Boer Wars) prevented dreams and plans from being realised. The opening of a Pretoria division of the Transvaal University College (TUC) in 1908 created new opportunities, but it would take another eight years before planning for theological training at the TUC could start. The NHK and the Presbyterian Church were involved as denominational partners in this undertaking. This phase lasted from 1917 to 1933. These humble beginnings laid the foundation for the theological training of ministers at university level - a paradigm which is still applicable in South Africa today.
\end{abstract}

\section{INTRODUCTION}

The run-up to, founding and first period of the Faculty of Divinity at the Transvaal University College is an interesting part of the history of the Transvaal, and more specifically of the history of the "Nederduitsch Hervormde Kerk van Afrika" (NHKA) (translation: Netherdutch Reformed Church of Africa). The realisation of the need and later of the urgency for the church to train candidate ministers runs like a golden thread through the history of the NHKA. A study of the debate as it was conducted and developed over the years is important to gain an understanding of the spirit, 
theological tradition and culture of the NHKA and eventually too of the way in which the Faculty of Theology was formed. ${ }^{1}$

On the occasion of the centenary celebrations of the University of Pretoria, this article is intended to look once again at the turbulent history preceding the founding of the Faculty of Theology, and which in a certain sense characterised the first period that began in 1884 and continued until 1933. What occurred in the social, cultural, political and ideological fields inevitably spilled over to the ecclesiastical, theological and educational fields. The reason for selecting 1933 as the cut-off point is that a new dispensation began in the history of the Faculty of Theology in 1934 when the "Nederduitsch Hervormde of Gereformeerde Kerk" (NH/GK) entered as training partner. In 1938 the Faculty was divided into two denominational sections and a start was made with phasing out the duplex ordo in favour of a simplex ordo.

Chronologically the events can be summarised as follows:

1884

1885-1886

Rev C W du Toit proposed a draft resolution in the General Synod of the NHKA that the church should itself provide for the training of ministers.

Unification between the NHKA and Nederduitsch Gereformeerde Kerk (NGK) took place (forming the Nederduitsch Hervormde or Gereformeerde Church), but also led to disharmony and social unrest when a certain section of the NHKA refused to unite, thus continuing the NHK. Later another section (led by the so-called Procuration Commission) left the union and returned to the NHK.

1890 Deacon M J Willemse approached the General Synod with a draft resolution that the NHKA should itself begin training "sons of the land" as ministers.

1893 Elder $\mathrm{C} J$ Joubert proposed a similar draft resolution, once again without practical results.

1897 The General Synod decided to send candidates to the State Gymnasium in Pretoria with a view to preparing them for theological training.

1899 The Volksraad (National Assembly) of the Transvaal Republic (ZAR) decided to begin a university in Pretoria, which would include a theological faculty.

1899-1902 Second Anglo-Boer War.

1903 The Transvaal Technical Institute (TTI) was established with its main seat in Johannesburg.

\footnotetext{
${ }^{1}$ See for example Loader (1989).
} 
1906 The TTI became the "Transvaal University College" (TUC).

1907-1909 Prof P J Muller trained two candidate ministers.

1908 The Pretoria division of the TUC began teaching in Kya Rosa.

1909 The General Synod of the NHKA decided to begin a seminary.

Trustees were nominated.

1910 The Union of South Africa was established.

1912 The seminary project was abandoned.

1916 The General Synod decided to approach the TUC with a view to establishing a theological faculty in Pretoria. Consensus was reached between the TUC Council, the NHKA and the Presbyterian Church.

1917 The Minister granted approval. The TUC Council reached a formal decision to establish the Faculty of Divinity.

1918 The Faculty of Divinity opened officially with two Presbyterian lecturers and one NHKA lecturer.

1923 The TUC adopted Afrikaans in addition to English as a medium of instruction.

1927-1928 The University Commission of the National Party government recommended that the Faculty of Theology should offer only post-BD studies. Premier Hertzog rejected this recommendation.

1930 The TUC became the University of Pretoria.

1933 The Presbyterian Church withdrew from the Faculty of Theology. The "Nederduitsch Hervormde of Gereformeerde Kerk" (NH/GK) tentatively took its place.

1937 The NH/GK decided to join the Faculty of Theology as full partner. The University of Pretoria decided to divide the Faculty into two denominational sections.

\section{RUN-UP TO THEOLOGICAL TRAINING FOR THE NHKA}

Due to the disruptive effects of the Second Anglo-Boer War and the fact that the post-war situation differed in so many respects from the pre-war situation, it makes sense to divide this part of our historical account along these lines.

\subsection{Preceding the Second Anglo-Boer War}

It is generally known that there was no question of organised national education in the Transvaal before the time of President T F Burgers. Shortly after he became President of the Transvaal Republic (formal name: "ZuidAfrikaansche Republiek" (ZAR)) in 1872, he became profoundly aware of the pressing need for education. With his own hand, he wrote the draft of the ZAR's first education act (Act No 4 of 1874, commencing on 23 February 1876). Though it provided for the three levels of education and Burgers even envisioned a "hoogere school" (school of higher learning, i.e. university), little 


\section{The contribution of the Netherdutch Reformed Church (NHKA)}

came of it. The British annexation of the Transvaal shattered his dreams. His act was repealed in 1880 by the annexation authority ( $A D$ 1960:1).

After the First Anglo-Boer War and the restoration of the ZAR, education became one of the government's priorities. This is evident from the fact that the new education act was Act No 1 (the first Act of 1882). It was drafted by Rev S J du Toit, the Cape campaigner for the Afrikaans language, who was appointed the Superintendent of Education in the Transvaal. This Act also envisaged tertiary education, including the construction of a "normalskool op de zetelplaats" ("normal school in the capital" - "normal" in the sense of "training") (Pretoria) to train officials and teachers and generally to bring a proper scientific training within the reach of the white population of the ZAR (as cited in $A D$ 1960:1). It is interesting, however, that the Act did not mention theological training. Later (1890) Rev du Toit revealed that he was not in favour of a faculty of theology ( $A D$ 1960:3).

De Volkstem writes on 7 July 1883: "We hope to see the day of a university coming into existence in Pretoria offering training in the important subjects of learning and science ..." (cited in $A D$ 1960:2).

The first mention of the idea that the NHKA would itself have to provide some kind of training to meet its need to serve its congregations, is found in the draft resolution of the Rev C W du Toit (brother to the above-mentioned Rev S J du Toit) in the General Synod of $1884 .^{2}$ The delegates were not ready for this, however, and the debate ended in a non-committal decision (Engelbrecht 1953:362).

In May 1889 the Executive Council of the ZAR raised the possibility of an "Institution of Higher Learning or a University". The Volksraad (National Assembly) resolved on 12 June 1889 to build a university in Pretoria and budgeted £20 000 for the project. Dr W J Leyds and Rev S J du Toit were then requested to seek academicians in Europe who would get such an institution going in Pretoria. The requirement, however, was that lecturers had to be God-fearing and have appreciation for the national character of the Transvaal (AD 1960:2).

But the dreams of a "hoogeskool" (university) for the ZAR would take a long time to reach fulfilment. Meanwhile a secondary school was established in Pretoria with "Master" Wessel Louis as principal. It was a huge step forward at the level of secondary education. ${ }^{3}$ This was followed in 1893 by the wellknown Staatsgimnasium (State Gymnasium) with Dr H T Reinink as its first

\footnotetext{
${ }^{2}$ In the reconstruction years following the Second Anglo-Boer War, Rev C W du Toit played a major role in the NHKA, even at an advanced age. He remained interested in the matter of theological training right to the end.

${ }^{3}$ The name "Meester Louis" appears repeatedly in the minutes of the General Synod.
} 
principal. ${ }^{4}$ This, too, was a secondary education institution, although the standard of teaching was so high that it would not be inappropriate to claim that the transition to tertiary education had already been made (Ploeger 1970).

The need for an own theological training was expressed again on 28 April 1890 in an anonymous letter in De Volkstem. The letter advocated a theological school for the training of ministers, giving several reasons, especially the high cost of training ministers in the Netherlands. Later that year, Deacon M J Willemse van Roossenekal (probably the writer of the above-mentioned letter) submitted a draft resolution to the General Synod, proposing that seminary training for "sons of the land" should be established (Engelbrecht 1953:362). The chairman, Rev M J Goddefroy, took a stance against the proposal of a seminary. He expressed himself in favour of theological training at university level. This emphasis on university education would become the dominant view in the Netherdutch Reformed Church of Africa, even when a decision was taken at one stage that, as there was no university, a seminary should after all be instituted (Loader 1989:414). Goddefroy's opposition to a seminary led to the synod giving its support anew to theological training in the Netherlands, and Deacon Willemse's concern about costs was allayed by referring to the bursary opportunities which had become possible through "[our] brothers in the Netherlands" and the ZAR government.

At the General Synod of 1893, a draft resolution along the same lines as Deacon Willemse's proposal was submitted by Elder $\mathrm{C} J$ Joubert. This time the synod instructed the Commission of the General Synod to investigate the matter. The aftermath of the partially successful (or unsuccessful) union of the NHKA and NGK and the return of congregations under the leadership of the Procuration Commission required the lion's share of effort in the next few years, however, so much so that little came of the investigation (Engelbrecht 1953:363).

Dr N Mansvelt succeeded the Rev $\mathrm{S} \mathrm{J}$ du Toit as Superintendent of Education in 1892. Dr Mansvelt was not enthusiastic about a university in the ZAR. He preferred that candidates should be sent to the Netherlands for tertiary training. Nevertheless, on the orders of the ZAR government, he prepared a bill in 1896 with a view to establishing such a university. Unfortunately it never progressed past the bill stage ( $A D$ 1960:3).

Meanwhile the University of the Cape of Good Hope was founded in 1873 as the examining body of the various colleges that had already been

\footnotetext{
${ }^{4}$ It is also significant that $\mathrm{Dr} \mathrm{H} \mathrm{T} \mathrm{Reinink} \mathrm{(classicist)} \mathrm{had} \mathrm{been} \mathrm{a} \mathrm{lecturer} \mathrm{at} \mathrm{the} \mathrm{Theological}$ School of the Christian Reformed Church at Kampen before he took up this position.
} 


\section{The contribution of the Netherdutch Reformed Church (NHKA)}

established in the Cape Colony. In 1896 the Transvaal Republic was invited to form tertiary institutions under the umbrella of this university. Dr Mansvelt was not in favour of this, because he, like the ZAR government, was suspicious of the influence of the British in the Cape.

At the General Synod of the NHKA in 1897 a more positive climate prevailed than at previous meetings. A draft resolution of the Pretoria congregation led to the decision that candidates would be sent to the State Gymnasium with a view to preparing them for theological training. Elder A D W Wolmarans (prominent Transvaal politician) came to the fore as a prime proponent of an own theological training. Pursuant to the draft resolution of the Rustenburg congregation that the NHKA should build its own school for the training of ministers, he formulated a proposal for the General Synod of 1899 with a fundraising plan and suggestions for forming such an institution. The proposal was accepted (Engelbrecht 1953:363). Loader (1989:420) states that it was a choice in favour of a seminary which, because of the urgent need at that stage, was not opposed, not even by Goddefroy.

Meanwhile schools of a high standard were established in Johannesburg (thanks to generous financial support from mining magnates). Naturally they were tailored on the British model and obviously they did not in the least try to accommodate the national character of the Transvaal. Initiatives from the same sources to found a mining school were forestalled by the ZAR government when in 1897 the "Mijnschool der Zuid-Afrikaansche Republiek" (Mining School of the South African Republic) was founded in Johannesburg. At its head was the geologist Dr H G Breyer. This was the precursor to the Transvaal Technical Institute, which later became the Transvaal University College ${ }^{5}(A D$ 1960:3).

On 10 March 1899 the Volksraad (National Assembly) of the ZAR decided to form a university in Pretoria. Interestingly enough, it was the strong plea of the very same A D W Wolmarans mentioned above, that persuaded the Volksraad. This time Theology was mentioned by name as one of the fields of study. The government invited the NHKA to collaborate $(A D$ 1960:164). The government once again began seeking academics in the Netherlands who could begin teaching Law and Divinity in 1900. At last it seemed as if the dream of theological training at university level would come true. But the outbreak of the Second Anglo-Boer War in October 1899 thwarted all plans (Engelbrecht 1953:364).

\footnotetext{
${ }^{5}$ Dr Breyer would later be an important ally of General J C Smuts in his attempts to establish a fully fledged division of the TUC in Pretoria.
} 


\subsection{After the Second Anglo-Boer War}

The first General Synod of the NHKA after the war could only meet again on 8 June 1903. The destructive effects of war would persist long after the peace treaty was signed in May 1902.

It appeared that long before the peace treaty, the occupation government in Transvaal led by Lord Milner had already begun making plans to reorganise education. For example, E B Sargant was designated as Director of Education. Not only was the enormous need in the field of education realised, but education was also seen as a primary instrument for systematically carrying out an Anglicisation policy. Milner regarded the latter as of cardinal importance if Britain was to consolidate its gains in southern Africa.

Sargant wrote to Milner on 26 April 1901 about the necessity of beginning as soon as possible with planning a "teaching university for the two new colonies" ( $A D$ 1960:4). Sargant took the initiative himself, which led to the founding of the "Transvaal Technical Institute" (TTI) on 17 August 1903. Dr H G Breyer, mentioned above, was appointed in 1904 as a lecturer at the TTI to teach Mathematics and Physics by way of "evening classes" in Pretoria. Another name that deserves mention is that of Adv G T Morice who began teaching Roman-Dutch Law in Pretoria in the same year (also as a lecturer at the TTI) (AD 1960:5).

An interesting development from the NHKA's point of view was the arrival of two ministers of church from the Netherlands in 1904, namely Rev L E Brandt and Prof Dr P J Muller, who would play a valuable role in the postwar reconstruction of the NHKA. Prof Muller served until 1909 as the minister of the Pretoria congregation of the NHKA, and then returned to the Netherlands. He was also Moderator of the General Synod from 1907 until his departure.

Rev Jac van Belkum, who played a vital role in the reconstruction of the NHKA, ${ }^{6}$ wrote a letter on 4 April 1905 to Elder A D W Wolmarans, about the need for an own theological training. The discussions, action and decisions emanating from this eventually led to Prof Muller being requested to train two candidates to be ministers of religion, namely $\mathrm{J} J$ Kuhn and $\mathrm{J} J$ Prinsloo. This was interesting in the sense that it was a completely informal training (but nevertheless with the knowledge of the Commission of the General Synod). He continued with this for three years and, before his return to the Netherlands, he could present the two gentlemen as candidates to the Commission. After the Commission had examined them and found them suitable, they were legitimised and made available for calling. Both served

\footnotetext{
${ }^{6}$ See Engelbrecht (1953:367-368) for a commendation of Rev Jac van Belkum.
} 


\section{The contribution of the Netherdutch Reformed Church (NHKA)}

long and fruitfully in the service of the NHKA (Engelbrecht 1953:367-368; also Loader 1989:422).

By 1906 the whole southern Africa was aware of the need for a properly organised university system, and a great deal was spoken and written about this. This would continue for the next decade ( $A D$ 1960:7). Meanwhile the lecturers of the TTI began feeling ever more strongly that the institution had to have a wider scope. Partly as a result of their insistence, the Council of TTI decided on 25 May 1906 that the name should be changed to the "Transvaal University College" (TUC). The High Commissioner, Lord Selborne, formally opened the TUC on 1 August 1906 (AD 1960:6). It would prepare students for the examinations of the University of the Cape of Good Hope.

In 1907 General JC Smuts was appointed as Colonial Secretary to the cabinet of General Louis Botha (Transvaal Colony), with among other things the portfolio of education. It soon became clear that he had his own plans for the development of the Transvaal University College (TUC). He also put them implacably into effect, mostly against the will and desires of the TUC Council. The plans comprised dividing the TUC into three parts, namely (1) technology and mining, (2) agriculture and (3) the arts and basic sciences. The first part would be situated in Johannesburg and the last part in Pretoria, but as yet there was no clarity about the agricultural campus ( $A D$ 1960:8-11).

As General Smuts had envisaged, the Pretoria division of the TUC began its operations in 1908 with four professors and 32 students, in a house called Kya Rosa. This attracted so little attention that it was quite some time before residents in the area realised that they had acquired a university college as a neighbour. The medium of instruction was English.

It is understandable that although the ideal of theological training at university level still remained alive in the NHKA, under these circumstances it was not regarded as a realistic possibility. That was why Rev van Belkum and Elder Wolmarans increasingly began to think in the direction of a seminary. This idea was successfully argued in the General Synod of 1909. That the advocates of this idea were well prepared, is clear from a document entitled "Examination Rules regarding Admission to the Ministry of the Netherdutch Reformed Church of South Africa" which was tabled at the same meeting (Van Nieuwenhuizen 1974:24). The meeting decided that planning of a seminary should proceed. A Board of Trustees was appointed to carry out the instruction.

In 1910 Prof PJ Muller was nominated as a lecturer, but he did not see his way clear to undertaking this work. Unfortunately a doctrinal disciplinary case was taking place against one of the learned ministers of the NHKA, Rev 
C J L Ruysch van Dugteren, at that same time. Due to the attention it got and the bitter aftertaste it left, the Board of Trustees lost motivation for a while (Engelbrecht 1953:368). Only in 1912 did nominations begin again: this time two candidates who finished reading for their doctorates, namely Rev Jac van Belkum and Rev H C M Fourie. ${ }^{7}$ The latter responded negatively and when the General Synod met two months later, there was such strong resistance to a seminary that a resolution was taken to stop the entire project. For the time being, candidates would continue to be sent to the Netherlands. The Board of Trustees was not dissolved however, but continued to investigate ways and possibilities.

The Union of South Africa came into effect in 1910, leading to a new dispensation for education. The table was set for further developments in the field of university education. General Smuts announced the second step in his plan, namely that the Johannesburg and Pretoria divisions of the TUC should be separated and continue their existence as two separate incorporated institutions. In addition, the name TUC would be allocated to the Pretoria division and the Johannesburg division would be given a new name. This did in fact take place by means of Acts 1, 2 and 4 of 1910 ( $A D$ 1960:23). The new TUC would continue to operate as a constituent college of the University of the Cape of Good Hope.

\section{THE FACULTY OF DIVINITY BECAME A REALITY}

Since the University of the Cape of Good Hope had made provision for theological degrees, the possibility of theological training at the TUC was never excluded. As the TUC became stronger and greater confidence in the institution began developing, more voices expressed the view that a faculty of theology would be a valuable addition. The then Minister of Education, Advocate F S Malan, was approached with such a request by professors of the TUC in 1916. He was not unwilling. Without the one knowing officially about the other, the General Synod of the NHKA also decided to approach the TUC with a request to consider forming a theological faculty (May 1916), while the TUC Council decided shortly afterwards, at the insistence of the Pretoria newspaper editor, Dr FJ Engelenburg, to approach the NHKA with an enquiry, namely whether they would be interested in assisting with establishing such a faculty (15 June 1916).

Subsequently Dr Engelenburg was asked to compile a memorandum for the Council. This led to a commission of the TUC Council and delegates of Afrikaans and English churches assembling on 7 December 1916 to discuss

\footnotetext{
${ }^{7}$ Loader (1989:426-427) asserts that they were informally approached.
} 


\section{The contribution of the Netherdutch Reformed Church (NHKA)}

the founding of a multi-denominational theological faculty. Consensus was soon reached that such a faculty was desirable and necessary.

The matter was then taken over by the TUC's Educational Functions Committee. A feasible plan was devised. A recommendation was made that the NHKA and the Presbyterian Church should each provide a lecturer (namely Dr J H Greyvenstein and Rev E MacMillan respectively). Together they would receive one lecturer's salary, and the churches would be responsible for the rest of their remuneration. The Council accepted this recommendation on 21 December 1916 ( $A D$ 1960:165).

The Minister approved the founding of a theological faculty at the TUC, but at the same time stipulated that the Faculty could not operate officially before 1918. They first had to see how viable the project was. This would have meant that the faculty would have had to operate unofficially during 1917.

The TUC Council decided on 16 March 1917 to found a Faculty of Divinity. The Faculty would have opened officially on 1 April 1918 with Professor A C Paterson, Dr J H Greyvenstein and Rev E MacMillan (Engelbrecht 1953:369). The former was already in the service of the TUC, whereas the latter two were appointed as lecturers by their churches shortly after the Council decision. Rev MacMillan, unlike the other two lecturers, would at first work as a part-time lecturer. Prof Paterson was a Presbyterian, but not a nominee of the Presbyterian Church.

The year 1918 was a milestone in the university history of South Africa. The universities of Cape Town and Stellenbosch began operating as independent universities. The University of the Cape of Good Hope ceased to exist in the same year, and the University of South Africa was established with its main seat in Pretoria.

The TUC was one of the six constituent university colleges of the University of South Africa, which would have a federal structure. The colleges were permitted a high degree of discretion in teaching and examining. The table was set for the colleges to become autonomous. The first of the colleges to gain autonomy was the University College of Johannesburg, which in 1922 became the University of Witwatersrand (AD 1960:42-42).

\section{$3.1 \quad 1917-1924$}

In the TUC Calendar of 1919 (:19) we read:

Formal sanction of the Minister of Education was ... obtained for the establishment of a Faculty of Theology, with the work of which an informal beginning had already been made in the second 
semester of 1916, Professor Reinink undertaking the teaching in New Testament Greek, Professor Paterson that in Hebrew, while Dr JHJA Greijvenstein was appointed by the Kuratorium of the Hervormde Kerk as professor of Divinity in the interests of theological students of his own church.

The TUC Calendar of 1918 names the following people as theological lecturers: 8

- Lecturer: J H J A Greijvenstein, BA (Cape), ThD (Utrecht).

- Lecturer: E MacMillan, MA, BD (Glasgow).

When theological teaching began (in 1917), there were in total 214 students at the TUC. Initially there were four theological students, but one, Basson, cancelled his studies after a difference of opinion with the Board of Trustees. The others were P J J Venter (second-year), ${ }^{9} \mathrm{H}$ P Wolmarans and P S Grobler (both first-year students). Venter completed his training in 1920 and Wolmarans and Grobler in 1921. Wolmarans also completed an MA degree course in parallel with his BD degree.

\subsection{Initial syllabus}

The TUC Calendar of 1918 was the first calendar to indicate the theological syllabus:

\section{Draft curriculum for BD degree}

First Year Course: Latin, Greek, Dutch or English, a Physical or Social Science or History.

Second Year Course: Greek (including New Testament Greek), Hebrew, Latin or Dutch or English, Logic, Ethics.

Third Year Course: New Testament Greek, Hebrew, Elements and History of Metaphysics, Psychology.

Fourth Year Course: Old and New Testament Exegesis, Church History, Biblical Theology, History and Psychology of Religion.

Fifth Year Course: Old and New Testament Exegesis, Church History and History of Dogma, Philosophy of Theism and Religion, Christian Apologetics.

\footnotetext{
${ }^{8}$ Up to and including 1918 the calendar had been published with an English title only and Afrikaans versions for some English rubrics. From 1919 on the calendar appeared in English and Afrikaans versions. Interestingly enough, the Afrikaans version still contained a fair amount of English and the syllabi were shown under the title "Faculty of Theology" until 1938.

${ }^{9}$ Venter completed the first year of study at the Theological School, Potchefstroom.
} 
As can be seen, the theological training (including propaedeutics) took only five years. Since it is known that the BD course comprised only the last two years, this exposition seems rather strange. According to the 1919 Calendar, the syllabus changed little. It remained unchanged up to and including the TUC Calendar of 1922.

The BD syllabus is reflected in more detail in the TUC Calendar of 1920. This was also the year when the first students (H P Wolmarans and P S Grobler) began taking the BD course. Guidance had to be given to $P \mathrm{~J} J$ Venter earlier. He did not register for a BD, but took the candidate course on which the Commission of the General Synod and the Board of Trustees (NHKA) had decided on 12 February 1914, when there was still the intention to found a seminary. The course consisted of a preparatory examination, a candidate's examination in two parts and a church examination and was followed by a proponent's examination which he wrote on 13 April 1921 (Minutes: Commission Genl Synod, 12 February 1914).

\subsection{Early lecturers}

\subsubsection{Prof A C Paterson}

From the founding of the Transvaal University College in 1908 until his departure for New Zealand in 1924, Prof A C Paterson was professor of Classical Languages and Hebrew. In addition he was (from 1916) the registrar and from 1 October 1918 the first principal. He is described by Greyvenstein as "the brightest Hebrew scholar in whole South Africa" (Minutes Genl Synod 1919:28).

During his absence on leave in 1918, the theological student $P \mathrm{~J} \mathrm{~J}$ Venter acted in his stead and gave the lectures in Hebrew. This drew criticism from the Board of Trustees (NHKA), and Prof Greyvenstein was required to give an explanation of the matter (Minutes Board of Trustees, 29 January 1918, 13 March 1918). In 1922-1923 Paterson was on leave again, and this time Rev E MacMillan stood in for the lectures.

Paterson occupied his position for a few more months after returning from leave. Early in 1924 he resigned to go to New Zealand where he had accepted a professorship (in Auckland) (Viljoen 1981:476). In spite of divided and interrupted attention, it can be accepted that Paterson laid a sound foundation for the teaching of Hebrew at this institution.

\subsubsection{Prof E MacMillan}

Rev E MacMillan was initially appointed as a part-time lecturer. On 27 October 1924 he was promoted to part-time professor. In addition to his university 
duties, he remained active in the church. For example, in 1924 he was elected as moderator of the General Assembly of the Presbyterian Church in South Africa.

His training in Glasgow (MA, BD) had equipped him well for his task, but some people regarded his theology as "totally modernist" (Minutes Board of Trustees, 22 July 1919). His primary teaching responsibility was History of Religion and Philosophy of Religion. In addition, he taught Old Testament Exegesis.

It is known that he had studied in Germany in addition to his studies in Scotland, but he never obtained his doctoral degree. In 1930 he received an honorary doctorate from Glasgow (Minutes Faculty of Divinity, 29 August 1930).

In 1929 he joined the Oxford Group. This association took up more and more of his time. In 1930 he went to Scotland and England as a representative. In 1932 he took leave for the whole year to organise the movement in South Africa and to attend congresses abroad (AD 1960:166167).

With his balanced and pleasant manner, Prof MacMillan helped to consolidate the Faculty and to lay a sound basis for future growth. Rev J G M Dreyer writes in Die Hervormer of 22 November 1944 (after MacMillan's death): "By his sincerity, his ability, his noble character he commanded the respect of many." In Ad Destinatum 1960 he is described as an enthusiast with great drive and perseverance, a special personality and as pleasant in his dealings (1960:167). He resigned from University of Pretoria on 1 July 1933.

\subsubsection{Prof J H J A Greyvenstein}

Prof J H J A Greyvenstein was born on 17 March 1878 in the Barkley-East district of the Cape Colony. During the Anglo-Boer War he took up arms as a Cape rebel against the British colonial regime. In terms of the conditions of the Peace of Vereeniging, he escaped prosecution when hostilities ceased.

After the war he enrolled at the Seminary at Stellenbosch where he wrote his candidate's examination in 1905 and received legitimacy. After this he left to further his studies abroad. The plan was initially to study at a Scots university but when he arrived there he found that the academic year had already progressed far. He then went to Utrecht in the Netherlands, where he enrolled at the local State University. Lengthy studies in Ethics followed and led to a thesis on the social utilitarianism of Bentham (January 1911). After successfully defending his thesis, he returned to South Africa later that year (Van Nieuwenhuizen 1976:34-35). 
For the next four years he served a section of the NG congregation in Cape Town, in a temporary capacity. His earlier history as a Cape rebel might have been a factor in the reason that a full-time calling eluded him.

Rev C W du Toit heard about him and got into touch with him. After considerable persuasion, Dr Greyvenstein accepted the call to the NHKA congregation in Pretoria in April 1914. There he served until he was nominated by the Board of Trustees in March 1917 as lecturer of the Faculty to be founded. He accepted service on 1 April 1917. His teaching task was twofold: as lecturer of the TUC: New Testament and Christian Ethics; as lecturer of the NHKA: Dogmatics and Practical Theology (Van Nieuwenhuizen 1976:35).

\subsubsection{Prof SP Engelbrecht}

A significant development took place in 1921 when the TUC Council decided to appoint another lecturer. This was Dr S P Engelbrecht who had completed his doctoral studies in the previous year in the Netherlands, with the thesis "Geschiedenis van de Nederduitsch Hervormde Kerk in Zuid-Afrika" (The history of the Netherdutch Reformed Church in South Africa) ${ }^{10} \mathrm{He}$ was the first son of the NHKA to become a lecturer in the Faculty of Divinity. The Engelbrecht family had been an esteemed family in the Eastern Transvaal. However, his father died in the Anglo-Boer War and due to the British scorched-earth policy the family became impoverished. He completed his school education with difficulty. When he arrived in Utrecht in 1913, he was older than his fellow-students. Nevertheless he proved to be a hard-working and bright student (Pont 1992:262).

On 15 April 1921 the Board of Trustees also nominated him as NHKA lecturer.

With the arrival of Dr Engelbrecht, a golden age dawned for scholarship in the field of South African Church History. He was a diligent and thorough researcher with a well-developed sense for source material. Besides Church History, he also interested himself in the history of the ZAR (for example his monumental research on President T F Burgers). In addition to supervising theological theses, he acted as a supervisor for theses on South African history in the Department of History (Faculty of Arts).

The NHKA's Archives Repository was built up around his extensive collection of archival material and is accounted to be one of the best archival collections in South Africa.

\footnotetext{
${ }^{10}$ See Pont (1992:261-270) for an extensive discussion of Prof S P Engelbrecht's life and work.
} 
With the appointment of Dr Engelbrecht, the NHKA had two lecturers. Paterson left in 1924 and the Presbyterian Church was left with one lecturer (MacMillan). In the meantime the Faculty was growing steadily. Since theological students stayed on the campus for longer than most of the other students, the Hervormde students had a particular influence on campus life and student politics. For this reason, the objections that had been raised within the NHKA to the training gradually died down (Van Nieuwenhuizen 1976:41-42).

Dr Engelbrecht and Rev MacMillan were both promoted to professor in 1924.

\section{$3.4 \quad 1923$}

The 1923 Calendar shows that the BD course was extended to three years and the syllabi were adjusted accordingly.

The 1923 TUC Calendar names the theological lecturers as follows:

- Hebrew and OT Exegesis

Professor: A C Paterson, MA (Edin \& Oxon)

- NT Divinity and Exegesis

Professor: J H J A Greyvenstein, BA (Cape), ThD (Utrecht)

- OT Divinity and Exegesis, as well as

- Ecclesiastical History and History of Dogma

Senior lecturer: S P Engelbrecht, ThD (Utrecht)

- Apologetics

Lecturer: E MacMillan, MA, BD (Glasgow)

- Philosophy of Religion

Lecturer: CHS Runge, BA (Oxon)

- Greek

Professor: H Reinink, Litt D (Amsterdam)

- Metaphysics

Professor: WA Macfadyen, MA (Oxon), LLD (Cape)

- Social economics

Professor: JE Holloway, BA (Cape), DSc (London).

The 1924 TUC Calendar no longer shows names such as Runge, Reinink, Macfadyen and Holloway on the list of lecturers in the Faculty. Of Runge little is known and it is not clear what became of him. The omission of the other names indicates that the Faculty of Theology had now developed a clearer identity to distinguish itself from the Faculty of Arts. The assumption is reinforced by the fact that for the first time, a Dean of the Faculty is mentioned, namely Prof Greyvenstein. 
The above-mentioned syllabi do not correspond with what is indicated in the calendars and what the teaching responsibilities of the lecturers indicated. The list of lecturers in the 1923 TUC Calendar mentions that Rev MacMillan is responsible for Apologetics and Mr Runge for Philosophy of Religion. In the period 1924-1926 the latter subject disappeared from the list of lecturers, though Prof MacMillan is still indicated as lecturer in Apologetics. In 1927 it was Apologetic's turn to disappear and MacMillan is shown as lecturer in Philosophy of Religion. This lasted until the end of 1937, according to the calendars, although Prof MacMillan had left by the middle of 1933.

The year 1923 was of great interest for the Faculty of Theology for another reason too. The Council of the TUC adopted the policy of parallel teaching (in English and Afrikaans) on 23 June 1923 in so far as this could be economically justified. Since the students of the Faculty were Afrikaansspeaking, it was obvious that Afrikaans would become the medium of instruction. For the time being the lecturers could themselves decide which language they would use as the medium of instruction, so Paterson and MacMillan would have been able to continue teaching in English ( $A D$ 1976:55).

This change in policy came after a period of student agitation (supported by some lecturers). It was clear that although the English-speaking Establishment still had a strong influence on the TUC, Afrikaner students were increasingly making their presence felt, to such an extent that the institution was called a "hot-bed of nationalism" (AD 1976:56).

After the Council had taken the above-mentioned decision, the situation calmed down and only in 1929 would the language issue flare up again. Prof Paterson who, owing to his role in university management, became involved in various political issues. He found circumstances increasingly stressful and oppressive, and in 1923 resigned from the service of the TUC.

After Prof Paterson left, Prof S P Engelbrecht acted as lecturer in Hebrew. (As can be seen above, Prof Engelbrecht was at that stage already teaching Old Testament Exegesis and Theology.)

\section{$3.5 \quad 1925-1933$}

The TUC Council immediately advertised for a replacement. Four applications were received, including one from a rabbi and another from Dr B Gemser who was at that stage a Reformed minister at Lutjegast, Groningen (Netherlands). After the Council decided to appoint Dr Gemser as professor (October 1925), the Board of Trustees of the NHKA also nominated him as lecturer in Old Testament Exegesis and Theology (12 November 1925). This would ensure 
that he retained his status as minister of religion. Shortly after his arrival he also began teaching the subject Cultural History of Antiquity.

The then Minister of Education, Dr D F Malan, was reluctant at first to approve Dr Gemser's appointment, since Dr Malan already had a restructuring of the universities in mind. After Prof S P Engelbrecht and the TUC Council made representations, however, the Prime Minister, General J B M Hertzog, nevertheless approved Dr Gemser's appointment. This was the first warning of problems to come (Van Nieuwenhuizen 1976:44-45).

\subsubsection{Prof B Gemser}

Berend Gemser was born on 17 May 1890 in the North-Holland village of Broek. ${ }^{11}$ His father (a minister himself) died young, leaving the family in financial straits. This motivated the young Gemser to achieve at school and university (Böhl 1963:58; Van Selms 1981:185). After writing the doctoral examination in Theology at the State University of Groningen in 1917, he entered the service of the church. At the same time he began his doctoral studies in Semitic Languages. He obtained his doctoral degree with distinction (16 October 1924), with a thesis titled: "De betekenis der Persoonsnamen voor onze kennis van het leren and denken der oude Babyloniërs en Assyriërs" (The importance of personal names in our understanding of ancient Babylonian and Assyrian worldview and thought). This work made him wellknown throughout all of Europe and in America (Mulder 1951:86-87).

The chair to which the TUC appointed Gemser was in "Semitics" which had been established as a department in the Faculty of Arts thanks to donations from Jewish firms. A few firms continued their donations until late in the 1930s. Rabbi Hirsch of the Pretoria Hebrew Congregation was the intermediary. The chair attracted many postgraduate Jewish students over the years.

Prof Gemser therefore filled two professorial chairs right from the outset. His arrival gave Hebrew a fully fledged status as a subject since it could for the first time be taken as a major subject. His entry to the lecturer corps heralded a fruitful time in the scholarship of Semitic linguistics and Old Testament Studies in Pretoria. He is described by one of his students, Prof J P Oberholzer, as an "enthusiastic scholar, a solid theologian and a humble Christian” (Oberholzer 1992:84).

\subsection{Departments of the Faculty of Divinity}

The division of the Faculty of Divinity into departments is evident from a memorandum which Prof B Gemser compiled on behalf of the Faculty on 26

${ }^{11}$ See Oberholzer (1992) for an extensive discussion of Prof B Gemser's life and work. 
April 1926. The departments were as follows: Department of Old Testament Studies, Department of New Testament Studies, Department of Church History and Department of Comparative Religion (Engelbrecht Collection IV /14/2, in Van Nieuwenhuizen 1974:46, 52). The group of ecclesiastical subjects is not reflected in the memorandum.

The paradigm underlying the Faculty's handling of theology is evident from the regulations on the DD course contained in the 1931 Calendar. There the theological field is divided into three groups:

- Literature group (Biblical Exegesis, General and Particular Introduction, Biblical Theology, Cultural-Historical Background).

- Historical group (Church History, History of Dogma, Church Polity)

- Philosophical group (Ethics, Philosophy of Religion).

This classification of theology reflects a Science of Religion approach and corresponds broadly with the views that formed the foundation of duplex ordo.

\subsection{The Faculty of Theology comes under pressure}

In the years 1927-1928 the then Minister of Education, Dr D F Malan, ordered an investigation into South African universities. A "University Commission" (also called the Van der Horst Commission) was designated to examine, among other things, the place of the theological faculty at the TUC. It was the time when an economic recession was beginning to take hold worldwide. The Union Government was under great pressure to cut costs. This trend also rippled out to education.

The said commission was critical of the fact that three of the four theological lecturers at the TUC were members of the NHKA and interpreted this as government support for the NHKA. The commission typically used the seminary model as a norm, because it recommended the abolition of the $\mathrm{BD}$ degree course. At most theological training at post-BD level could be allowed at a university (Report of University Commission 1928, in Van Nieuwenhuizen 1974:48, 52).

Prof S P Engelbrecht gave an extensive memorandum on 20 September 1928 in response to the report. In it he refers to the financial contribution that the NHKA made at that stage to the Faculty of Divinity. He also explained the duplex ordo according to which the university and the partner churches offered Theology and ministerial training. The university part of the theological training comprised the general academic subjects for which any student could register, whereas courses in the ecclesiastical subjects, 
such as Dogmatics and Practical Theology, were arranged and funded entirely by the churches. He claimed that the recommendations of the University Commission were tantamount to maligning the traditional standing of Theology at European and UK universities. After all, the BD degree had already been awarded by the University of the Cape of Good Hope. He also pointed out the logical inconsistency of claiming that post-BD teaching was in order at a university, but BD teaching itself was not (Engelbrecht Collection IV /14/3, in Van Nieuwenhuizen 1974:50, 52).

Fortunately the Prime Minister at that time, General J B M Hertzog, intervened once again and thwarted the plans of his Minister of Education regarding the Faculty of Divinity.

The irony that theological training at the TUC was threatened when the the National Party was in power, was not overlooked in the NHKA. This contrasted starkly with the Faculty's experience with the previous regime. It left Prof S P Engelbrecht with an aftertaste which influenced his political views for many years.

\subsection{TUC became University of Pretoria and Afrikaans}

As mentioned above, the University of Witwatersrand was established in 1922. One of the objections to this was that it would herald an exodus of university colleges from the University of South Africa. Even then, it was predicted that the TUC would be the next to demand independence. For mainly economic reasons, this happened only in 1930 when, in terms of Private Act No. 13 of 1930, the TUC became the University of Pretoria. At that stage the university had close to 1000 students and 144 staff members. The first principal of UP was Prof A E du Toit (AD 1960:43-44).

The language issue would flare up again in 1929. Students began complaining that teaching in some faculties was predominantly in English. The Extramural Division in particular was well-known for giving little or no teaching in Afrikaans. The Afrikaans Students League took the lead in the agitation for language equity.

That year, the principal, Prof A E du Toit, expressed himself in favour of UP becoming Afrikaans: “... TUC should serve the rural, mainly Afrikaans speaking population of greater Transvaal." Afterwards he would consistently campaign for this and even regarded the gaining of independence by the TUC as an essential step in this direction ( $A D$ 1960:57).

In 1930 the UP Council reluctantly reconciled itself to the principle of language equity. In practice, however, there was little change, for example because many lecturers could not speak Afrikaans and Afrikaans had not yet developed sufficiently as a language of science. 
The language issue was eventually revealed to be a cultural-political issue. The English-speaking and Afrikaans-speaking groups of lecturers and students increasingly stood alongside and opposite each other as two separate worlds. It took the fairly trivial incident of a defamatory book against the Afrikaners, leading to the tarring and feathering of the supposed author, H P Lamont, who was a lecturer in the Department of French, to flare up into an enormous issue. Relations soured so much between the two language groups that a motion of distrust in the principal was proposed in both the Senate and Council. After Prof du Toit survived this, he began with renewed conviction and determination to campaign for UP to become Afrikaans. After a great deal of emotional outpour and drama, the Council consented to such a policy change on 13 September 1932 (AD 1960:56-67).

The action in the NHKA which had by then been continuing for many years and had been aimed at moving the theological training to the Potchefstroom University College, died a natural death after this.

Shortly afterwards the Presbyterian Church withdrew as a training partner. It had become clear that the Presbyterian Church had little interest left in the Faculty of Theology - as a matter of fact, not a single Presbyterian minister had ever been trained there. This trend strengthened as the training increasingly developed a more obviously Afrikaans character. After Prof MacMillan resigned in 1933, no other Presbyterian was nominated as a theological lecturer. In this way, an important phase in the developmental history of the Faculty would come to an end - a history which would not have been possible without the partnership between the two churches.

After the departure of the Presbyterian Church, the Dutch Reformed Church (Nederduitsch Hervormde or Gereformeerde Church as the union church was known at that stage - later renamed as the "Nederduitse Gereformeerde Kerk van Transvaal") was invited to take part in the Faculty of Theology. A new situation arose, which differed in many respects from the previous one. The difference would gradually become ever greater.

The experience with the Minister of Education convinced the NHKA of the necessity of entering into an official contractual agreement with the UP. This happened in 1934.

\section{EPILOGUE}

The turbulent history preceding and later accompanying theological training at TUC (later UP) tends to divert attention from the interesting developments in theological training as such that took place in Pretoria. It was the first training that ministers had ever received at a theological faculty in South Africa. At that stage, theological training had taken place at denominational seminaries (as 
in Stellenbosch and Potchefstroom). The University of the Cape of Good Hope had indeed provided for theological examinations and qualifications, but the TUC was the first university college that had taken the step towards actually presenting theological training.

Furthermore the involvement of church partners made it possible for the TUC to found and develop a faculty of theology. The church partners were not merely recipients of benefits, but made a substantial contribution to the economic viability of the Faculty of Theology. The fact that it had been arranged according to the principle of the duplex ordo seemed in 1928 to be an important argument in the debate about the recommendations of the University Commission. ${ }^{12}$

The period lasting to 1933 had its logical conclusion in 1934 with the formal agreement between UP and the NHKA. This became the precursor to the later notarial contracts between the two Dutch Reformed churches (NHKA and NGK) and the University of Pretoria. A former Principal of UP, Prof $\mathrm{C} \mathrm{H}$ Rautenbach, asserted that these notarial contracts were a worldwide first and a unique arrangement at that. ${ }^{13}$

In this way, the foundation was laid for the future development of theological training at universities, not only in Pretoria but also at other universities. The Faculty of Theology can therefore be regarded as a pioneer in South Africa of this kind of theological training.

At the same time, the high academic standard that had been maintained from the outset, was a guarantee of continued quality. The later development and expansion of the Faculty in its two sections could proceed on a path that had been clearly delineated.

\section{Works consulted}

Ad Destinatum 1960. Gedenkboek van die Universiteit van Pretoria 1910-1960. Johannesburg: Voortrekker Printers. (Referred to as " $A D$ 1960")

Engelbrecht, S P 1953. Geskiedenis van die Nederduitsch Hervormde Kerk van Afrika. Kaapstad-Pretoria: HAUM-De Bussy.

Commission of the General Synod 1913. Minutes 1913-01-29.

Loader, J A 1989. Ontstaan en eerste periode van die Hervormde teologiese opleiding aan die Universiteit van Pretoria. HTS 45(2), 412-437.

Mulder, E S 1951. Die wetenskaplike betekenis van die werk van professor B Gemser. HTS 7, 85-96.

Oberholzer, J P 1992. Berend Gemser, hoogleraar 1926-1955. HTS 48, 83-100.

\footnotetext{
${ }^{12} \mathrm{~A}$ great many of the points of criticism raised by the commission sound familiar and could just as easily have been stated in the contemporary debate on whether or not theological training at university could be justified.

${ }^{13}$ Personal communication.
} 
Ploeger, J 1970. Die "Staatsgymnasium" te Pretoria: 'n pêrel aan die kroon van die onderwysstelsel in die "Zuid-Afrikaansche Republiek". Almanak en Bybelse Dagboek 64, 35-47.

Pont, A D 1992. Kerkgeskiedenis in ons teologiese opleiding. HTS 48, 253-272.

Van Nieuwenhuizen, T H J 1974. Ontstaan en geskiedenis van die teologiese fakulteit (Afd A) aan die Universiteit van Pretoria: 'n Oorsig. BD dissertation, University of Pretoria.

Viljoen, G van N 1981: Paterson, Alfred Croom. SABW 5, 476 